\title{
A note on carcass characteristics of adult Japanese quail fed on recycled quail manure
}

\author{
V. Chrappa, V. Sabo, K. Bod̆a and Helena Strážnická \\ Institute of Animal Biochemistry and Genetics, Slovak Academy of Sciences \\ 90028 Ivanka pri Dunaji, C-SRF
}

(Received 4 May 1992; accepted 6 July 1992)

KEY WORDS: Japanese quail, manure recycling, carcass analysis

INTRODUCTION

The importance of Japanese quail as an experimental object and farm animal is increasing (Boda, 1986; Baumgartner et al., 1985; Baumgartner, 1990). It is therefore necessary to identify the parts of its body that can be utilized in human nutrition and those to be considered by-products. Tserveni et al. (1986) analyzed the carcass characteristics of 6-week-old Japanese quail of both sexes. They found that at this age the trunk, breast and thigh weight was similar in both sexes, but the relative weight of the liver and gastrointestinal tract was higher in females than in males.

The parameters of the most significant carcass parts of three lines of Japanese quail at the age of 35 days were also given by Baumgartner et al. (1985) and Baumgartner (1990). Šebová (1988), investigating the growth rate of Japanese quail in the post-natal period found that in the breast and wings of 10 week old birds the proportion of muscles and bones was highest and of the skin lowest.

Attempts have been undertaken to recycle Japanese quail manure and utilize the biomass contained in it. Chrappa et al. (1990) did not find any significant difference in the performance of two generations of Japanese quail fed on isoprotein and isoenergetic diets without or with a $20 \%$ content of dried quail manure.

There is no data concerning carcass evaluation of adult quails after a distinct egg-laying period, especially with regard to manure recycling.

The aim of the experiment was to assess and quantitatively compare carcass parameters of 26 week-old female and male birds fed on mash diets with or without dried quail manure. 
MATERIAL AND METHODS

Japanese quails of both sexes were fed to appetite within 20 -week laying period on isoprotein and isoenergetic diets with or without a $20 \%$ content of recycled dried quail manure.

At the age of 26 weeks, 15 female and 15 male quails from each group, having a body mass (BM) close to the average BM for group, were selected. They were held for 18 hours without feed, then individually weighed and slaughtered by cutting their throats and bleeding. Following slaughter the carcasses were weighed again and the weight of blood calculated from the difference. Next they were plucked, weighed again and the weight of feathers calculated. The carcasses were then eviscerated and divided into single parts, the weight of each part was recorded. The trunk with bones, heart, liver, gizzard, abdominal fat, ovary with non-laid eggs, and testicles were considered edible parts. Blood, feathers, head, legs, neck and remnants of the digestive tract were considered carcass waste.

The trunk was cut into breast, legs, wings and back. The weight of each part with bones was recorded, then it was cooked, the bones removed and weighed, and the weight of meat calculated from the difference. All bones were included into carcass waste from which meat and bone meal was produced by pressure hydrolysis.

Data for control and manure fed groups of males and females were compared using the Student's t test.

\section{RESULTS AND DISCUSSION}

Results of carcass analysis are presented in Table 1. In both groups females in comparison with males had a distinctively higher $\mathrm{BM}$, but about $80 \%$ of this difference was due the weight of the ovaries. Trunks of birds of both sexes were of similar weight and there were no differences in dressing percentages between males and females. The trunks of male birds contained more meat than those of females. Females had heavier livers, wings and more carcass waste but lighter heads and less abdominal fat than males.

Male and female quails fed on diets with manure had a lighter bones in comparison with the control birds. No pronounced differences in yield of edible and nonedible parts were found between birds of both sexes fed on control or manure diets.

From the point of view of recycling, the utilization of carcass waste is also very important. The composition of meals produced from the carcass waste is shown in Table 2. Meals produced from carcass waste of female birds contained more crude protein but less fat than that from male birds. Meat-and-bone meal produced from the carcass waste of birds fed on the manure diet had about $3 \%$ more crude protein than meal from control birds. No significant differences were found among other parameters 
Table 1

Carcass analysis

\begin{tabular}{|c|c|c|c|c|c|c|c|}
\hline & & & & & G r & $\mathrm{p} \mathrm{s}$ & \\
\hline Indices, & $\mathrm{g}$ & & & C & ntrol & $20 \%$ & anure \\
\hline borim & & & & 우 & 0 & 우 & 0 \\
\hline Body mass & $\sec 5$ & & & 141.9 & $120.0^{* *}$ & 138.7 & $121.6^{* *}$ \\
\hline Trunk (with & bones): & & & 80.1 & 81.2 & 79.6 & 81.6 \\
\hline breast & $8 x+2$ & 34.82 & & 33.1 & 33.7 & 32.8 & 33.4 \\
\hline thighs & & es int & & 18.9 & 18.6 & 19.1 & 18.9 \\
\hline wings & $132 \pi 1$ & & & 6.9 & $6.3^{*}$ & 7.0 & $6.3^{* *}$ \\
\hline back & 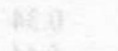 & & & 21.2 & 22.6 & 20.7 & 23.0 \\
\hline Giblets: & & & & 24.3 & 9.4 & 24.0 & $10.2^{* *}$ \\
\hline heart & & & & 0.8 & 0.7 & 1.1 & $0.9^{* *}$ \\
\hline liver & & & & 3.4 & 1.3 & 3.6 & $1.6^{* *}$ \\
\hline gizzard & & & & 1.7 & $1.4^{*}$ & 2.3 & $1.6^{* *}$ \\
\hline abdomi & nal fat & & & 0.4 & $2.8 * *$ & 0.0 & $2.6 * *$ \\
\hline ovary & & & & 18.4 & - & 17.0 & - \\
\hline testes & & & 28.2 & - & 3.2 & - & 3.5 \\
\hline Carcass was & te (offals) & & $\operatorname{csta}^{2}$ & 37.6 & $30.1^{* *}$ & 35.3 & $29.9 * *$ \\
\hline blood & & & & 5.5 & $3.9^{* *}$ & 5.5 & $4.4^{* *}$ \\
\hline feathers & & & & 6.6 & $5.0^{* *}$ & 6.6 & $5.9^{*}$ \\
\hline head & & & & 5.3 & $6.2 * *$ & 5.8 & 6.0 \\
\hline legs & & & & 2.1 & $1.8^{* *}$ & 2.6 & $2.2^{* *}$ \\
\hline neck & & & & 2.3 & 2.1 & 2.6 & 2.6 \\
\hline other w & astes & & & 15.8 & $11.1^{* *}$ & 12.2 & $8.8^{* *}$ \\
\hline Meat total: & & & & 72.0 & 73.2 & 72.4 & 74.6 \\
\hline breast & & & & 32.2 & 32.6 & 31.9 & 32.4 \\
\hline thighs & & & & 17.0 & 16.8 & 17.2 & 17.4 \\
\hline wings & & & & 5.2 & 4.8 & 5.7 & $4.9^{*}$ \\
\hline back & & & & 17.6 & 19.0 & 17.6 & 19.9 \\
\hline Bones (from & trunk) & & & 8.5 & 8.0 & 7.2 & 7.0 \\
\hline Meat and ec & lible gible & & & 96.3 & 82.6 & 96.4 & 84.8 \\
\hline Wastes (bon & es and of & fals) & & 46.1 & 38.1 & 42.5 & 36.9 \\
\hline Dressing per & centage & & & 73.6 & 74.9 & 74.7 & 75.5 \\
\hline
\end{tabular}

The difference between males and females of the same group:

* $-\mathrm{P} \leqslant 0.05 ; * *-\mathrm{P} \leqslant 0.01$ 
Table 2

Composition of meals produced from carcass wastes

\begin{tabular}{|c|c|c|c|c|c|c|}
\hline \multirow{3}{*}{ Indices, $\%$} & \multicolumn{6}{|c|}{ Groups } \\
\hline & \multicolumn{3}{|c|}{ Control } & \multicolumn{3}{|c|}{$20 \%$ manure } \\
\hline & Q & c) & mixed & ? & $\delta^{\pi}$ & mixed \\
\hline Water & 9.59 & 7.40 & 8.50 & 8.49 & 7.28 & 7.89 \\
\hline Dry matter & 90.41 & 92.60 & 91.51 & $91.5 \mathrm{k}$ & 92.72 & 92.12 \\
\hline Crude protein $(\mathrm{N} \times 6.25)$ & 55.17 & 51.71 & 53.44 & 58.44 & 54.53 & 56.49 \\
\hline Crude fat & 15.12 & 21.79 & 18.46 & 14.49 & 20.28 & 17.39 \\
\hline Crude ash & 17.87 & 16.37 & 17.12 & 17.56 & 16.84 & 17.20 \\
\hline Crude fibre & 0.49 & 0.39 & 0.44 & 0.77 & 0.34 & 0.56 \\
\hline $\mathrm{Ca}$ & 5.78 & 5.53 & 5.66 & 5.76 & 5.44 & 5.60 \\
\hline $\mathbf{P}$ & 3.00 & 2.79 & 2.90 & 2.91 & 2.85 & 2.88 \\
\hline \multicolumn{7}{|l|}{ Aminoacids: } \\
\hline Asp & & & 4.36 & & & 4.08 \\
\hline Thr & & & 2.56 & & & 2.39 \\
\hline Ser & & & 3.98 & & & 3.90 \\
\hline Glu & & & 6.33 & & & 6.09 \\
\hline Pro & & & 4.27 & & & 4.15 \\
\hline Gly & & & 4.52 & & & 4.38 \\
\hline Ala & & & 3.07 & & & 2.89 \\
\hline Val & & & 2.94 & & & 2.72 \\
\hline Ile & & & 1.97 & & & 1.80 \\
\hline Leu & & & 4.13 & & & 3.83 \\
\hline Tyr & & & 1.77 & & & 1.83 \\
\hline Phe & & & 2.26 & & & 2.13 \\
\hline His & & & 1.45 & & & 1.33 \\
\hline Lys & & & 2.26 & & & 2.02 \\
\hline Arg & & & 2.91 & & & 2.94 \\
\hline
\end{tabular}

\section{REFERENCES}

Baumgartner J., Kočiová E., Polanská O., 1985. Carcass utilization of egg-type Japanese quail. Hydin. pokrok. 3, 117-123

Baumgartner J. (Ed.), 1990. Japanese quail as laboratory animal. Veda, Vyd. SAV, Ser. C, Vet. Bratislava, pp. 100

Boda K., 1986. Will yiclding animals fulfil their function also in cosmic conditions? Veda, technika, technická práca, 23-27

Chrappa V., Sabo V., Bod̆a K., Abelová H., 1990. Feeding recycled manure in isoprotein and isoenergetic feed mashes to two generations of Japanese quail. In: K. Boda (Ed.). Current trend in cosmic biology and medicine. I. Ivanka pri Dunaji, pp. 301-306

Šebová K., 1988. Live weight growth in the head, neck, trunk, breast and wings of Japanese quail in the post-natal period. Pol'nohospodárstvo, 34, 854-869

Tserveni-Gousi A.S., Yannakopoulos A.L., 1986. Carcass characteristics of Japanese quail at 42 days of age. Br. Poultry Sci. 27, 123-127 
STRESZCZENIE

Skład tuszy dorosłych przepiórek japońskich żywionych odchodami przepiórczymi

Oznaczono skład tuszy 26-tygodniowych kurek i kogutków przepiórki japońskiej, po 20 tygodniowej produkcji jaj przez kury, żywionych dawkami pasz bez (grupa kontrolna) lub z 20\% udziałem suszonych odchodów drobiowych (grupa doświadczalna). Zawartość białka ogólnego w dawce doświadczalnej była większa niż w kontrolnej.

Kurki były istotnie cięższe niż kogutki, co było następstwem ciężaru jajników, cięższej wątroby i większej ilości odpadów, przy mniejszej zawartości tłuszczu wewnętrznego. Nie stwierdzono natomiast istotnych różnic w ciężarze korpusu, całej tuszy i wydajności rzeźnej. Ptaki żywione dawką doświadczalną miały lżejsze kości, lecz wydajność części jadalnych i niejadalnych była podobna jak w grupie kontrolnej.

Mączka mięsno-kostna wyprodukowana $\mathrm{z}$ odpadów tuszek kurek zawierała więcej białka, a mniej tłuszczu niż z odpadów tusz kogutków. 